\title{
The Effect of Problem Based Learning (PBL) towards Critical Thinking Used Computer Simulation
}

\author{
Mariati Simanjuntak ${ }^{1}$, Chatarina Purba ${ }^{2}$, Berta Panggabean ${ }^{3}$, Azmi Mustafa $^{4}$, Juniar \\ Hutahaean $^{5}$ \\ \{mariati_ps@yahoo.co.id ${ }^{1}$, chatarinamsp@gmail.com ${ }^{2}$, bertamasrifapanggabean@gmail.com ${ }^{3}$ \} \\ Department of Science Education, State University of Medan ${ }^{1}$, Department of Physics Education, \\ State University of Medan ${ }^{2}$, Department of Physics Education, State University of Medan ${ }^{3}$
}

\begin{abstract}
This study aims to examine the effect of PBL used simulation named adobe flash on critical thinking skills. The research was quasi-experimental using a pretestposttest control group design. The population of this study was all of the 11th graders at one of SMA in Medan. The sample class experiment using PBL were used adobe flash and control using traditional. The Data were collected by the student's critical thinking test based on the contextual problem in an essay. The Data were analyzed by using a t-test and $\mathrm{N}$-Gain. The results indicated resources that the pretest scores for the experimental and control group were 38.93 and 36.25 and the posttest scores were 74.45 and 53.95. Based on the result of the t-test, there was a significant effect between critical thinking skills applied PBL used with adobe flash.
\end{abstract}

Keywords: Problem-based Learning, Critical Thinking, Computer Simulation

\section{Introduction}

The development of the $21^{\text {st }}$ century has a significant impact on the community. People are increasingly aware of the importance of preparing young people to be able to meet the demands of the 21 st-century skills are a must-have in the 21 st century are grouped into three sections, namely learning and innovation skills (critical thinking, innovation, creativity, and problemsolving), information and technology skills (information and media literacy and technology literacy) and life and career skills (skills social skills, adaptability, leadership, productivity and being flexible [1].

Critical thinking is one of the 21 st-century life skills need to be developed through a process of education. Critical thinking is a fundamental skill in learning in the 21 st century that can be trained through education [2]. Critical thinking is the ability to give reasons in an organized and evaluate the quality of a reason systematically [3]. Critical thinking is a process, the aim is to make sensible decisions about what to believe and what to do [4]. A person who has the skills of critical thinking tends to more quickly identify relevant information, separate the irrelevant information and use that information to find solutions problem or make a decision, and if necessary seek the relevant supporting information. Critical thinking is also able to enhance one's creativity and serves also for reflection or self-evaluation of the decisions that have been taken [2].

One of the subjects that provide the opportunity to develop students' critical thinking is a physics lesson. Physics is one branch of Natural Sciences (IPA) which provides knowledge of 
the universe as well as interaction within it. Physics can be used as a tool to train the ability to think critically and analytically in a problem-solving both qualitatively and quantitatively and to develop the knowledge, skills, and confidence. Physics can train critical thinking skills of students as it is essentially a process of learning physics is to define the concepts, principles, theories, and laws of nature, as well as to cause a reaction, or an answer that can be understood and accepted in an objective, fair and rational. Physics has a very important role because of the phenomena that occur in nature very closely related to physics and in everyday life, for example, the phenomenon of sound, light, motion, and force.

The importance of critical thinking skills students is not in accordance with the facts on the ground. Based on preliminary studies using baseline testing in one high school in Medan showed that $80 \%$ of students have a lower critical thinking skill. Initial results were confirmed by interviews conducted by the researchers. Based on interviews of students showed when asked to give an argument about a problem student was silent and could not give his argument, in concluding the settlement problem students also found it difficult. Students also have not been able to determine which action to solve a problem.

One of the causes of the low critical thinking skills of students for learning presented in the classroom is still traditional. The learning-centered teacher, presents only a theory, formula, example problems which emphasizes mathematically so that students lacking an argument, do not facilitate the students to decide a course of action to resolve the problem so as to make the students can only receive an answer from the teacher alone, does not present phenomena / the problem to be solved, and does not provide an opportunity for students to make a further explanation of the phenomenon in life.

Based on these descriptions, critical thinking skills are very needed to be provided to students so that students can solve problems logically and creatively. One effective learning model that is suspected to increase creative thinking and critical thinking of students is a problem-based learning (problem-based learning, (PBL), PBL is a set of teaching models that use the issue as a focus to develop critical thinking skills, problem-solving, materials, and selfregulation [5], PBL is a model that provides a variety of problem situations authentic and meaningful, providing a space for investigation and investigation of the problem and support student learning [6]. The aim of PBL is to help students develop critical thinking skills, problemsolving abilities, and intellectual skills, to study the role of adults and become independent and autonomous learning. PBL challenges students to solve authentic problems in the informationrich settings [7], PBL begins with the assumption that the learning process is active, integrated and constructive designed to make students independent learners, working together to solve problems and learn to find out [8], PBL model is effectively used to enhance students' critical thinking as the primary goal rather than a model of PBL is not the delivery of the majority of knowledge to the students, but rather on the development of critical thinking skills and problem resolution [9]. PBL can increase students' ability to think critically and develop their ability to adapt to new knowledge [10].

The use of PBL models will be more interesting if the maximum and collaborated with the use of instructional media, either a simple or a technology-based media. Instructional media are all means of communication such as printing, graphics, animation, audio and audiovisual that can be used to deliver learning [11]. One media-based technology that can be used for learning is a computer simulation model of PBL. Computer simulation is a visualization computergenerated from real-world objects that provide the environment, context and situation that almost authentic learning task-based and computer simulations allow students to see the events, processes, and activities that others may not have been available to them through the involvement interactive [12], Computer simulations can provide an opportunity for students not 
only to develop students' understanding and strengthening of the concept but also develop their skills in scientific investigation and inquiry. In addition, computer simulations are also able to enhance students' critical thinking skills. The use of computer simulations in the model PBL can improve students' critical thinking skills for computer simulation can stimulate the curiosity of students to find solutions to the problems presented [13], This is also supported by [14] which states that the use of computer simulation models assisted PBL provides a positive effect on critical thinking skills.

Based on the exposure mentioned above, this study aims to investigate the influence of PBL models using computer simulations of the students' critical thinking skills.

\section{Methods}

This study was conducted in one high school in the city of Medan in the second semester of 2018/2019 consisting of 4 classes totaling 196 people. The sampling technique was conducted on cluster random sampling. The sample in this study consisted of two classes of grade XI IPA 2 totaling 44 people as an experimental class taught by a model problem based learning using computer simulations and XI 4 as many as 40 people as the control class is taught by conventional teaching. This research is a quasi-experimental and design used is a two-groupposttest pretest just as shown in Table 1 .

Table 1. Two Group Pretest - Posttest Design.

\begin{tabular}{llll}
\hline Class & Pretest & Treatment & Posttest \\
\hline Experiment & $\mathrm{Y}$ & $\mathrm{X} 1$ & $\mathrm{Y}$ \\
Control & $\mathrm{Y}$ & $\mathrm{X} 2$ & $\mathrm{Y}$ \\
\hline
\end{tabular}

$\mathrm{X} 1=$ Problem based learning using computer simulations in $11^{\text {th }}$ grade

$\mathrm{X} 2$ = Conventional learning on the material grade optical $11^{\text {th }}$ grade

$\mathrm{Y}=$ Pretest and posttest were given the experimental class and control class before and after treatment.

The research instrument is a test of critical thinking skills in the subject matter of optical devices with sub-loop material, microscopes, eyeglasses, cameras, mirrors, and lenses. The instrument comes in the form of a problem-based essay as many as 10 items that have been validated in content and construct. The hypothesis test used was t-test. As a prerequisite before the test t-test, data from the two classes should be normal and homogeneous. Normality test, homogeneity, and t-test were performed using SPSS. Percentage increase in critical thinking skills is calculated using the formula $\mathrm{N}$-Gain, namely equation (1):

$$
g=\frac{\text { posttest score-pretest score }}{\text { maximal score-pretest score }}
$$




\section{Results and Discussion}

Before starting the study, two classes were given an initial capability test (pretest) of critical thinking skills with the results shown in Table 2.

Table 2. Pretest Data of Critical Thinking Skills in Control and Experiment Class.

\begin{tabular}{|c|c|c|c|c|c|c|}
\hline \multicolumn{3}{|c|}{ Control Class } & \multicolumn{3}{|c|}{ Experiment Class } & \multirow[b]{2}{*}{$\begin{array}{l}\text { Homogeneity } \\
\text { (Sig) }\end{array}$} \\
\hline $\begin{array}{c}\text { Range of } \\
\text { Values }\end{array}$ & $\begin{array}{c}\text { Frequenc } \\
\mathrm{y}\end{array}$ & $\begin{array}{c}\text { Normalit } \\
\mathrm{y} \\
\text { (Sig) }\end{array}$ & $\begin{array}{c}\text { Range of } \\
\text { Values }\end{array}$ & $\begin{array}{c}\text { Frequenc } \\
y\end{array}$ & $\begin{array}{c}\text { Normalit } \\
\text { y } \\
\text { (Sig) }\end{array}$ & \\
\hline $25-29$ & 9 & & $25-29$ & 1 & & \\
\hline $30-34$ & 5 & & $30-34$ & 9 & & \\
\hline $35-39$ & 8 & 0.69 & $35-39$ & 8 & 0.47 & 0.06 \\
\hline $40-44$ & 7 & & $40-44$ & 12 & & \\
\hline $45-49$ & 6 & & $45-49$ & 10 & & \\
\hline $50-54$ & 5 & & $50-54$ & 4 & & \\
\hline $\begin{array}{l}\text { Informatio } \\
\mathrm{n}\end{array}$ & $\bar{X}=36.25$ & Normal & $\begin{array}{l}\text { Informatio } \\
\mathrm{n}\end{array}$ & $\bar{X}=38.93$ & Normal & $\begin{array}{c}\text { Homogeneou } \\
\text { s }\end{array}$ \\
\hline
\end{tabular}

The experimental class treated with PBL using computer simulation and control classes were given conventional learning. Learning has been completed respectively in sub optical instrument material, the second class is a matter of critical thinking skills posttest identical to pretest questions that aim to look after the students' learning treated. The posttest results of critical thinking skills in this study are shown in Table 3.

Table 3. Posttest Data of Critical Thinking Skills in Control and Experiment Class.

\begin{tabular}{|c|c|c|c|c|c|c|}
\hline \multicolumn{3}{|c|}{ Control Class } & \multicolumn{3}{|c|}{ Experiment Class } & \multirow[b]{2}{*}{$\begin{array}{c}\text { Homogeneity } \\
\text { (Sig) }\end{array}$} \\
\hline $\begin{array}{l}\text { Range of } \\
\text { Values }\end{array}$ & Frequency & $\begin{array}{l}\text { Normality } \\
\text { (Sig) }\end{array}$ & $\begin{array}{l}\text { Range of } \\
\text { Values }\end{array}$ & Frequency & $\begin{array}{l}\text { Normality } \\
\text { (Sig) }\end{array}$ & \\
\hline $40-44$ & 8 & & $60-65$ & 4 & & \\
\hline $45-49$ & 7 & & $66-71$ & 13 & & \\
\hline $50-54$ & 6 & 0.49 & $72-77$ & 14 & 0.25 & 0.25 \\
\hline $55-59$ & 6 & & $78-83$ & 8 & & \\
\hline $60-64$ & 5 & & $84-89$ & 2 & & \\
\hline $65-69$ & 8 & & $90-95$ & 3 & & \\
\hline Information & $\overline{\mathrm{X}}=53.95$ & Normal & Information & $\overline{\mathrm{X}}=74.45$ & Normal & Homogeneous \\
\hline
\end{tabular}

After testing the prerequisites and have been known to a normal and homogeneous distribution of data, hypothesis testing is then performed using the t-test. The calculation result of hypothesis testing using t-test. The experiment and control of pretest data can be seen in Table 4. 
Table 4. Hypothesis Testing Pretest Critical Thinking Skills.

\begin{tabular}{lccc}
\hline \multicolumn{1}{c}{ Class } & Average & $\mathrm{T}$ & $\mathrm{T}_{\text {table }}$ \\
\hline Control & 19.00 & 1.875 & 1,992 \\
Experiment & 24.04 & & \\
\hline
\end{tabular}

Table 4 shows the early ability of critical thinking skills of students in the experimental class with students in the control class optical instrument material. Based on Table 4, it can be concluded if both classes have the same initial ability in critical thinking because the result of the $\mathrm{t}$-test is $\mathrm{t}<\mathrm{t}_{\text {table }}(1.875<1.992)$.

After giving a different treatment in the second grade, the posttest given and gained the ability of different end as shown in Table 5.

Table 5. Hypothesis Testing of Critical Thinking Skills' Posttest.

\begin{tabular}{lccc}
\hline \multicolumn{1}{c}{ Class } & Average & $\mathrm{T}$ & $\mathrm{t}_{\text {table }}$ \\
\hline Control & 53.95 & 11,14 & 1.66 \\
Experiment & 74.45 & & \\
\hline
\end{tabular}

Based on Table 5 shows that the average value posttest experimental class is higher than the control class and $t>t_{\text {table }}$ is $11.14>1.66$. Based on these results we can conclude that there are differences in the student's critical thinking skills due to the effect of problem-based learning models using computer simulations.

Based on the results of the posttest data analysis, both groups of students experienced an increase in $\mathrm{N}$-gain. The percentage increase in $\mathrm{N}$-gain to critical thinking skills is shown in Table 6.

Table 6. Percentage of Increasing Critical Thinking N-Gain for Experiment and Control Class.

\begin{tabular}{lll}
\hline Class & N-gain $(\%)$ & Category \\
\hline Experiment & $58 \%$ & Middle \\
Control & $28 \%$ & Low \\
\hline
\end{tabular}

A percentage increase in critical thinking can be seen with Gain Normalized (N-Gain). Percentage increase in N-Gain critical thinking experiment class $58 \%$ and $28 \%$ control. The maximum score of the items of critical thinking skills is 10. Each of the indicators is made in 2 critical thinking about.

Based on Table 6, the percentage increase in N-gain critical thinking in the experimental class higher than the class of control. The percentage of $\mathrm{N}$-gain experimental class was $58 \%$ in the medium category and the control class was $28 \%$ in the low category. The difference in $\mathrm{N}$ Gain of critical thinking between the experimental class and the control class is because, in the experimental class, students are taught with PBL models and given LKS which contains contextual problems that are close to students so that students are able to develop critical thinking skills so students are able to solve given problems. The difference in N-Gain is also influenced by the use of computer media, namely adobe flash-assisted computer simulations. Computer simulations are presented to help and train students in critical thinking. The simulation is designed to attract the attention of students so that they are more enthusiastic and happy in learning. With the existence of computer simulation assistance, students are more directed to think, argue, and find solutions to a problem. When students have finished practicum, 
students can compare the results of their practicum with computer simulations that have been made. If the results of their practicum are wrong, they can repeat it. This trains students to be better able to observe, provide arguments, and infer their practical results so that students' critical thinking skills increase.

Increased N-Gain critical thinking skills in the low control class $(28 \%)$ because students in the control class use the lecture method, question and answer, tend to continue to take notes and listen to the teacher's explanation. Students in conventional classes are still less active in learning activities, are not accustomed to observing problems and looking for solutions and only a small proportion of students dare to express their opinions. Students in problem-based learning classes are more active in learning, eager to conduct experiments, and some students are active in expressing opinions.

Based on the data analysis indicators of critical thinking skills have different $\mathrm{N}$-gain increases. The percentage increase in $\mathrm{N}$-ga in critical thinking skills is shown in Table 7.

Table 7. Percentage of Increasing N-Gain for Each Critical Thinking Skills Indicators.

\begin{tabular}{|c|c|c|c|c|c|c|c|c|}
\hline \multirow{2}{*}{$\begin{array}{l}\text { Critical Thinking } \\
\text { Indicators }\end{array}$} & \multicolumn{2}{|c|}{ Control Class } & \multirow{2}{*}{$\begin{array}{c}\mathrm{N} \\
\text { Gain } \\
(\%)\end{array}$} & \multirow[t]{2}{*}{ Criteria } & \multicolumn{2}{|c|}{ Experiment Class } & \multirow{2}{*}{$\begin{array}{c}\mathrm{N} \\
\text { Gain } \\
(\%)\end{array}$} & \multirow[t]{2}{*}{ Criteria } \\
\hline & Pretest & Postest & & & Pretest & Postest & & \\
\hline $\begin{array}{l}\text { Elementary } \\
\text { Clarification }\end{array}$ & 6,63 & 6.78 & 4 & low & 6.78 & 7.69 & 28 & Low \\
\hline Basic support & 3.13 & 6.48 & 49 & middle & 3.91 & 8.62 & 77 & high \\
\hline Interference & 2.92 & 4.95 & 29 & low & 3.28 & 7.3 & 60 & Middle \\
\hline $\begin{array}{l}\text { Advanced } \\
\text { Clarification }\end{array}$ & 1.51 & 4.9 & 40 & middle & 1.55 & 7.25 & 67 & Middle \\
\hline $\begin{array}{l}\text { Strategy and } \\
\text { tactics }\end{array}$ & 3.95 & 3.96 & 0.2 & low & 3.95 & 6.42 & 41 & Middle \\
\hline
\end{tabular}

Based on Table 7, it can be concluded that the basic support indicator has the highest percentage increase with a $77 \%$ increase. The increase in basic support indicators becomes the highest due to the fact that during learning in the experimental class, students are trained to solve problems by practicing (observing) and comparing the results obtained with reliable sources, such as textbooks. In addition, during the practicum (observation), students are also assisted with computer simulations that are adapted to the practicum that is being done so that students are better able to make observations. The lowest increase in critical thinking indicators is elementary clarification, which is $28 \%$. This is because students have not been able to focus questions appropriately, although there are some students who have been able to focus questions from the given problem.

Critical thinking skills of students by implementing PBL models using computer simulations better than the conventional one. For example, at the first meeting, in the first phase of learning, students are given an authentic problem-related material flat mirror. The problem given is how to make a room look spacious with an only used flat mirror. Some students begin trained to give a simple explanation to give a hypothesis to answer these problems. A similar trend was also made at the meeting II and III. Once briefed, had more students who are trying to provide hypotheses and on other issues that researchers give even a debate between students 
associated with the given hypothesis. After the treatment is given, the skills give a simple explanation of students' increased by $28 \%$.

The second phase was to organize students to learn. This organization provides a space for students to collaborate in investigating the problem. Students are divided into groups of 7 heterogeneous and researchers share Worksheet Students (LKPD) which presents a problem that explores the creative and critical thinking skills of students. Students in the group began to organize their strategies and tactics such as determining the things they would do in the lab, divide tasks during practicum, and identify action steps in LKPD together. Students also begin to build up their basic skills by finding reliable reading material on a flat mirror in each book.

The third phase is to assist the investigation independently and in groups. Investigations conducted in a group of student activities to construct their own knowledge through experimental activities that foster independent learning in students. Students began work in groups lab, lab results in data processing and make conclusions from the lab they can. When students do lab work, critical thinking of the five indicators.

The fourth phase is to develop and present the artifacts and the exhibit. In this phase, critical thinking skills indicators that summarize and make further explanation trained. Students are asked to present the group's work and concluded that they can be solutions. After being given the treatment, concluded skills as well as making further explanation students increased by $60 \%$ and $67 \%$.

The fifth phase is to evaluate the solution. This phase is intended to help students analyze and evaluate their thinking processes to present the work. Researchers guide students to synchronize the existing concept circuitry answers given each group in LKPD. Teacher as facilitator guide students to reflect on the process of the investigation conducted.

Computer simulations are presented to assist and train students to think critically. Simulations are designed to attract students more enthusiastic and happy in learning. The advantages of the model PBL using computer simulations including providing activity in the learning process so that teachers only act as a facilitator by providing orientation about the problem to the students, then the teachers to motivate students to get involved in addressing the problem, organizing students to examine, define and organizing tasks associated with the problem [16]. Aid simulation, students will also be easier to remember and know the physics concepts that are abstract. define and organize the tasks associated with the problem. Aid simulation, students will also be easier to remember and know the physics concepts that are abstract. define and organize the tasks associated with the problem. Aid simulation, students will also be easier to remember and know the physics concepts that are abstract.

\section{Conclusion}

Based on the results of this study, it can be concluded that there was the effect of problembased learning by computer simulation in improving student's critical thinking skills. The percentage of increase in critical thinking in control and experiment class was $27.8 \%$ and $57.8 \%$. 


\section{References}

[1] Ongarwanidch, N., Kanjanawasee, S., Tuipae, C.: Development of 21st Century Skill Scales as Perceived by Students. Journal of Social and Behavioral Sciences. Vol. 3 No. 2 (2015)

[2] Hidayah, R., Salimi, M., Susiani, T.S.: Critical Thinking Skill: Konsep dan Indikator Penilaian. Jurnal Taman Cendikia. Vol.3, No.2 (2017)

[3] Hossoubah, Z.: Developing Creative and Critical Thinking Skills (Terjemahan). Yayasan Nuansa Cendekia, Bandung (2007)

[4] Ennis, R.H.: Critical Thinking. Prentice Hall Inc., New Jersey (1996)

[5] Eggen,P. and Kauchak, D.: Strategi dan Model Pembelajaran Mengajarkan Konten dan Keterampilan Berpikir. Indeks, Jakarta (2012)

[6] Arends, R.I.: Learning To Teach. The Mc.Graw-Hill Inc, New York (2012)

[7] Birgli, B..: Creative and Critical Thinking Skills in Problem Based Learning Environment. Journal of Gifted Education and Creativity. Vol. 2, No.2 (2015)

[8] Argaw, A.S., Haile, B.B., Ayalew, B.T., Kuma, S.G.: The Effect of Problem Based Learning (PBL) Instruction on Student's Motivation and Problem Solving Skills of Physics. Journal of Mathematics Science and Technology Education. Vol. 13, No.3 (2017)

[9] Farisi, A., Hamid, A., Melvina: Pengaruh Model Pembelajaran PBL Terhadap Kemampuan Berpikir Kritis dalam Meningkatkan Hasil Belajar Peserta Didik pada Konsep Suhu dan Kalor. Jurnal Ilmiah Mahasiswa Pendidikan Fisika. Vol. 2, No.3 (2017)

[10] Sanjaya,W.: Strategi Pembelajaran Berorientasi Standar Proses Pendidikan. Kencana Prenada Media Group, Jakarta (2006)

[11] Omodara and Adu.: Relevance of Educational Media and Multimedia Technology for Effective Service Delivery in Teaching and Learning Processes. IOSR Journal of Research and Method in Education, Vol.4, No.2 (2014)

[12] Nkemakolam, O.E., Chinelo, O.F., Jane, M.C.: Effect of Computer Simulation on Secondary School Student's Academic in Chemistry in Anambra State. Asian Journal of Education and Training, Vol.4, No.4 (2018)

[13] Munandar, H., Sutrio, Taufik, M.: Pengaruh Model Pembelajaran Berbasis Masalah Berbantuan Media Animasi Terhadap Kemampuan Berpikir Kritis dan Hasil Belajar Siswa SMAN 5 Mataram Tahun Ajaran 2016/2017. Jurnal Pendidikan Fisika dan Teknologi, Vol. 4, No. 1 (2018)

[14] Santoso, R., Darmadi, I.W., Darsikin: Pengaruh Model Pembelajaran Berbasis Masalah Berbantuan Media Komputer Terhadap Kemampuan Berpikir Kritis Siswa SMA Negeri 5 Palu. Jurnal Pendidikan Fisika Tadulako (JPFT), Vol.4, No.2 (2016)

[15] Hake,R.R.: Interactive Enggagement V.S. Traditional Methods: Six-Thousand Student Survey of Mechanics Test Data for Introductory Physics Courses. American Journal of Physics. Vol. 66, No. 1 (1998)

[16] Hikmayanti, I., Saehana, S., Muslimin: Pengaruh Model Problem Based Learning Menggunakan Simulasi Komputer Terhadap Hasil Belajar Siswa pada Materi Gerak Lurus Kelas VII MTs Bou. Jurnal Pendidikan Fisika Tadulako (JPFT), Vol. 3, No. 3 (2015) 